\title{
Ethnomedicine of the Kagera Region, north western Tanzania. Part 2: The medicinal plants used in Katoro Ward, Bukoba District
}

\author{
Mainen J Moshi ${ }^{1^{*}}$, Donald F Otieno ${ }^{2}$, Pamela K Mbabazi ${ }^{3}$, Anke Weisheit ${ }^{3}$
}

\begin{abstract}
Background: The Kagera region of north western Tanzania has a rich culture of traditional medicine use and practices. The dynamic inter-ethnic interactions of different people from the surrounding countries constitute a rich reservoir of herbal based healing practices. This study, the second on an ongoing series, reports on the medicinal plant species used in Katoro ward, Bukoba District, and tries to use the literature to establish proof of the therapeutic claims.

Methodology: Ethnomedical information was collected using Semi-structured interviews in Kyamlaile and Kashaba villages of Katoro, and in roadside bushes on the way from Katoro to Bukoba through Kyaka. Data collected included the common/local names of the plants, parts used, the diseases treated, methods of preparation, dosage, frequency and duration of treatments. Information on toxicity and antidote were also collected. Literature was consulted to get corroborative information on similar ethnomedical claims and proven biological activities of the plants.

Results: Thirty three (33) plant species for treatement of 13 different disease categories were documented. The most frequently treated diseases were those categorized as specific diseases/conditions (23.8\% of all remedies) while eye diseases were the least treated using medicinal plants (1.5\% of all remedies). Literature reports support $47 \%$ of the claims including proven anti-malarial, anti-microbial and anti-inflammatory activity or similar ethnomedical uses. Leaves were the most frequently used plant part ( 20 species) followed by roots (13 species) while making of decoctions, pounding, squeezing, making infusions, burning and grinding to powder were the most common methods used to prepare a majority of the therapies.

Conclusion: Therapeutic claims made on plants used in traditional medicine in Katoro ward of Bukoba district are well supported by literature, with $47 \%$ of the claims having already been reported. This study further enhances the validity of plants used in traditional medicine in this region as resources that can be relied on to provide effective, accessible and affordable basic healthcare to the local communities. The plants documented also have the potential of being used in drug development and on farm domestication initiatives.
\end{abstract}

\section{Introduction}

The Kagera region has a magnificent culture of herbalism. While the Haya tribe dominates the region, there is a lot of knowledge exchange with the neighboring tribes like the Rukiga and Banyankore of Uganda, the Tutsi and the Hutu of Rwanda and Burundi who have all intermarried overtime bringing together an impressive

\footnotetext{
* Correspondence: mmoshi@muhas.ac.tz

'Department of Biological and Preclinical Studies, Institute of Traditional Medicine, MUHAS, P.O. Box 65001, Dar es Salaam, Tanzania
}

culture of herbal centered traditional medicine [1]. Thus when one talks to people belonging to different tribes within Kagera, regardless of their education status or age, what one hears is an impressive account of herbal therapies that have been used successfully to treat different diseases.

The first in the series of investigations on plants used in traditional medicine in the Kagera region reported on the plants used in Bugabo Ward [2]. This second part of the series provides a glimpse into the plants used in traditional medicine by Issack Kato and two of his 
colleagues; Maruzuku Mazimpaka and Hajat Nuria Kyejo, all who are traditional healers practicing in Katoro Ward. This study therefore adds to the continuing efforts to document [2], evaluate for biological activity [3-5], and identify how plant genetic resources in the Kagera region can be mainstreamed into the social and economic development of the local people, for example, through on-farm cultivation and the development of marketable medicinal plant products. The study is an ethnomedical documentation of medicinal plants in Katoro Ward of, Bukoba district, north western Tanzania.

\section{Methodology}

\section{Description of the study site}

Katoro is a ward within Bukoba district and lies on the south west of Bukoba town and situated at $1^{\circ} 23^{\prime} 59^{\prime \prime}$ South, $31^{\circ} 30^{\prime} 1^{\prime \prime}$ East (Figure 1). Like the rest of the Bukoba district, the Katoro ward has good rainfall and good vegetation cover that provides abundant resources for traditional medicines.

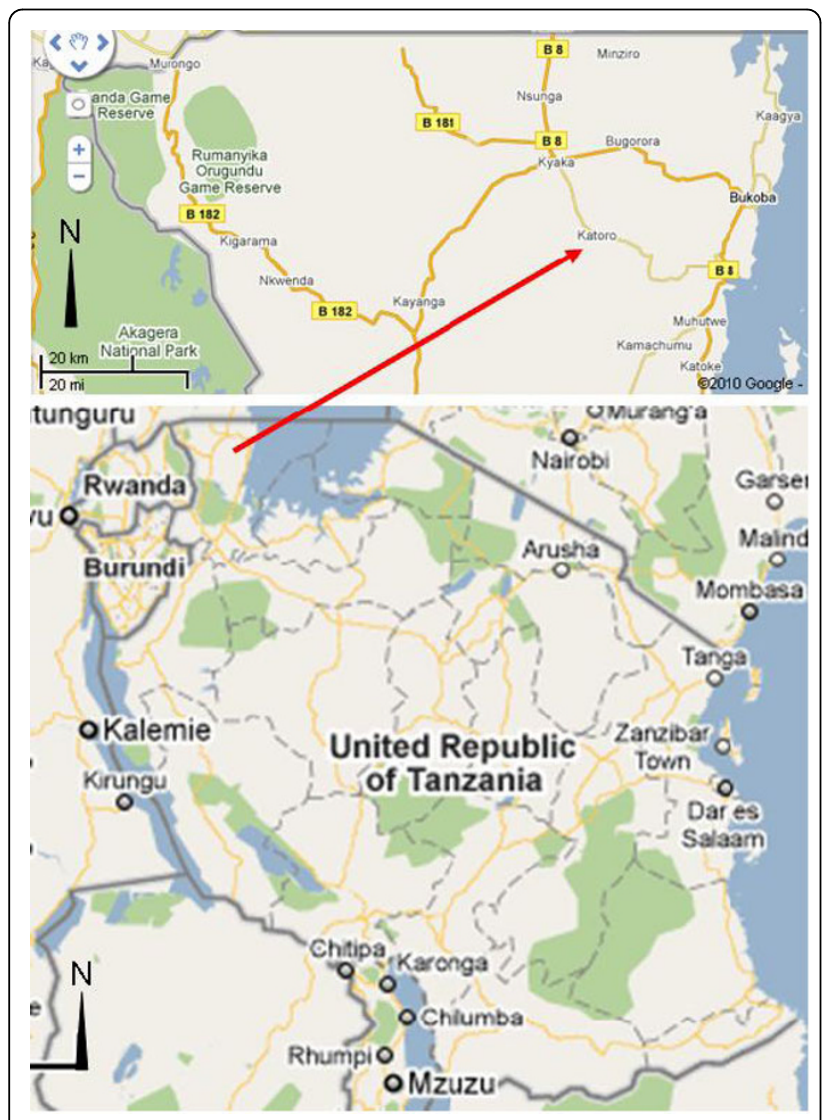

Figure 1 Map showing the study site at Katoro ward, Bukoba District (Source: Google Maps 2010).

\section{The Ethnobotanical visit and documentation of plant} information

Independently, the research team established contact with three informants (Issack Kato, Maruzuku Mazimpaka and Hajat Nuria Kyejo) who practice traditional medicine in Kashaba village in Katoro. A field visit was, thereafter, made to the area between $28^{\text {th }}$ February and $2^{\text {nd }}$ March, 2008. During this visit ethnomedical information was collected using semi-structured interviews [6] as the team walked, accompanied by the informants, through the banana farms, roadside and surrounding bushes and thickets of Kyamlaile and Kashaba villages. Voucher specimens were made for all plants collected and these were subsequently identified by Mr. Selemani Haji of the Department of Botany, University of Dar es Salaam. Duplicate vouchers are kept at the Herbaria of the Botany Department, University of Dar es Salaam, and that of the Institute of Traditional Medicine, Muhimbili University of Health and Allied Sciences.

\section{Literature survey to establish proof of claims}

Literature information was retrieved from the NAPRALERT data base at the School of Pharmacy, University of Illinois at Chicago. The strength of information obtained from the informants was evaluated based on its agreement with similar therapeutic claims in literature from elsewhere or evidence in literature of laboratory results that support the claims.

\section{Results}

Medicinal Plant diversity

A total of 33 plant species belonging to 31 genera and 19 plant families were documented (See additional file 1)). The largest proportion of medicinal plants collected belonged to the family Asteraceae (21\%), followed by Fabaceae (12.1\% each) and Euphorbiaceae (9.0\%). The main source of these plants in terms of number of species were trees (30.3\% of the total number of species) followed by shrubs (39.4\%) and herbs (21.2\%). The remaining $9.09 \%$ were climber herbs and shrubs.

\section{Diseases treated}

A wide variety of medical conditions were treated using remedies made from medicinal plants. Most of the plants used had more than a single therapeutic use. For example, Draceana steudneri was used for treating fibroids, splenomegaly and asthma. On the other hand, many diseases were also treated using a wide range of plants. Malaria for example, was treated using Senna alata, Clerodendrum myricoides, Dalbergia nitidula, Eriosema psoraleoides, Hygrophylla auriculata, Rhus vulgaris and Vernonia amygdalina. The most frequent ailments treated with medicinal plants were those categorized here as specific diseases/conditions (Table 1) 


\begin{tabular}{ll}
$\begin{array}{l}\text { Table } \mathbf{1} \text { Number of plant species used to treat diseases } \\
\text { within different disease categories (The disease } \\
\text { categories were adopted from Ssegawa and Kasenene, } \\
\text { 2007[40]) }\end{array}$ & Number of plants \\
\hline Disease Category & 2 \\
\hline Cardiovascular and circulatory & 6 \\
Gastro-intestinal diseases & 3 \\
Respiratory tract infections & 1 \\
Eye diseases & 4 \\
Female genital system & 3 \\
Skeletal muscular system & 7 \\
Skin diseases and subcutaneous tissue & 10 \\
Infectious diseases & 2 \\
Child hood diseases and conditions & 16 \\
Specific diseases and conditions &
\end{tabular}

comprising conditions like malaria, dysentery, cancer, yellow fever etc. and were treated using the largest number of remedies $(23.8 \%$ of all remedies). On the lower end, $1.5 \%$ of the remedies were used to treat eye diseases, $2.98 \%$ cardiovascular and circulatory diseases (e.g. anemia), $4.47 \%$ respiratory tract infections (e.g. chest pains) and $4.47 \%$ skeletal muscular problems (e.g. body spasms). Reproductive problems like difficulties to conceive and low libido were treated using $14.2 \%$ of all the remedies used.

\section{Plant parts used}

The plant parts used for making herbal preparations were the roots, leaves, stem bark, root bark, pods and other aerial parts. The leaves were the most frequently used ( 20 species) followed by the roots (13 species), and stem bark and other aerial parts (each 4 species). Other parts like the pods were also used, for example in Kigelia africana and the root bark in Parinari curatellifolia, but rarely.

\section{Herbal medicines and their preparation}

Mono therapies based on preparations made from a single plant were the most dominant, although many remedies where more than one plant was used were also common. Those that involved the use of two species included, for example, the boiling of Carissa tomentosa roots with the bark of Elaedendron buchananii or powders of the two being mixed and taken with tea or mixed with roots of Tragia furialis for the treatment of hernia, backache or taken as an aphrodisiac. Others included a decoction made from boiling the roots of Combretum collinum and Rhus vulgaris being drunk for the treatment of dysentery while another made from boiling the leaves of Dalbergia nitidula with the stem bark of Sapium ellipticum was used to treat malaria. Fresh leaves of Dichrocephala integrifolia were pounded with the leaves of Ageratum conyzoides and the juice squeezed out and applied to the eyes as an eye drop while for the treatment of indigestion, the leaves of Hoslundia opposita were mixed with the leaves of Ocimum basilicum, boiled and the decoction drunk. A decoction made from boiling the leaves of Pappea capensis with those of Vernonia brachycalyx was drunk for the treatment of backaches and to treat chickenpox, the leaves of Rhus natalensis mixed with those of Vernonia amygdalina were boiled and the decoction drunk. Treatments that involved the use of three or more plants in combination included, for example, the pounding of the roots and/or leaves of Desmodium salicifolium, Elaeodendron buchananii and Tragia furialis then boiling and taking the decoction as an aphrodisiac. Others included the treatment of skin rashes and joint pains and relieving of feet from burning sensations by applying the root or stem bark powder of Maytenus senegalensis mixed with the root powders of Rauvolfia vomitora, Parinari curatellifolia and Ozoroa insignis in a fat base. The treatment of yellow fever involved pounding and boiling the leaves of Trema orientalis with those of Combretum collinum and Erythrina abbysinica and taking the decoction. Backache was also treated using a decoction prepared from a combination of four different species. The decoction was made by boiling the root powder of Tragia furialis mixed with that of Elaeodendron buchananii or Spathodea campanulata and Carisa spinarum and then drunk or the powders were simply mixed with water and taken. A second treatment of malaria involved taking a decoction made from the leaves and/or roots of Vernonia amygdalina mixed with the stem bark of Rhus natalensis and the leaves of Dalbergia nitidula, Desmodium salicifolium and Eriosema psoraleoides. The most common methods used to prepare most of the therapies were making of decoctions (46.4\%), pounding (14.2\%), squeezing (10.7\%), making infusions (8.9\%), burning (7.1\%) and grinding to powder (5.4\%).

\section{Literature based proof of traditional healers' claims}

Out of all the plants used by traditional healers in Katoro, the uses of $47 \%$ of them (16 out of 34 species) are supported by reports of similar uses or proven biological activity in the literature. There were no reports of toxicity for any of the species except for Ageratum conyzoides reported to have caused toxicity to sheep [7]. The plants whose therapeutic claims are well supported by the literature include Ageratum conyzoides [8-10], Bidens pilosa [11-14], Boerhavia diffusa [15], Capparis tomentosa [16], Cassia alata [17-19], Clerodendrum myricoides [20,21]. Others are Combretum collinum [22], Dichrocephala integrifolia [23], Flueggea virosa [24,25], Hoslundia opposita [26], Jatropha curcas [27,28], Lantana camara [29-31], Melanthera scandens 
[32], Microglossa pyrifolia [33,34], Rubia cordifolia [35-37] and Vernonia amygdalina [32,38,39].

\section{Discussion}

This is the second of an ongoing series to document plants that are used in Kagera region, northwestern Tanzania, as traditional medicines. The plants that have been documented from Katoro are relatively few compared to the rich plant diversity that is known to be in the Kagera region [2]. However, the proportion of claims made by traditional healers in Katoro concerning some of the plants documented in this study and which are supported by literature evidence of proven biological activity or similar ethnomedical uses elsewhere is remarkable. Thus therapeutic claims made concerning; Ageratum conyzoides, Bidens pilosa, Boerhavia diffusa, Capparis tomentosa, Cassia alata, Clerodendrum myricoides, Combretum collinum, Dichrocephala integrifolia, Flueggea virosa, Hoslundia opposita Jatropha curcas, Lantana camara, Melanthera scandens, Microglossa pyrifolia, Rubia cordifolia and Vernonia amygdalina can be taken to be credible, given that these plants either have identical uses elsewhere or their biological activities have been proven. It has been suggested that the identical use of a medicinal plant by different people from different areas is often considered to be a good and reliable indicator of the plants curative properties [40].

The Kagera region is one place in Tanzania where there is a remarkable interchange of culture by ethnic groups from different countries e.g. the Rukiga and Banyankore of Uganda, the Tutsi and the Hutu of Rwanda and Burundi all who have intermarried over time bringing together an impressive culture of herbal centered traditional medicine [1]. This culture is indeed entrenched among the different ethnic groups in Kagera, and unlike other parts of Tanzania, people from all walks of life value traditional medicine, including even the well educated, who in other places would not so proudly talk of the benefits of traditional medicines.

Some plants previously documented in Kagera and used for the treatment of bacterial infections and wound healing [2] have been found to have antibacterial properties $[3,5]$ and results from brine shrimp toxicity tests also suggest that they have low toxicity [4]. This goes to show that Kagera region, within which Katoro falls, has a repository of plants that can be relied upon for the treatment of various illnesses that the local communities have to deal with now and again.

\section{Conclusion}

This study shows that the therapeutic claims made on plants used in traditional medicine in Katoro ward of
Bukoba district are credible given that $47 \%$ of the claims are well supported by the literature. It also enhances the validity of the plants as resources that can be relied on to provide effective and affordable healthcare to the local communities. The plants documented in this study thus also have the potential of being used in drug development and on farm domestication/cultivation initiatives.

\section{Additional material}

Additional file 1: Medicinal plants used in Katoro ward; Bukoba District. The file contains a list of medicinal plant species, their uses, parts used and methods of preparation, together with information from the literature supporting the traditional therapeutic claims.

\section{Acknowledgements}

We are grateful to the traditional healers who provided the information constituting this manuscript and their willingness to allow this information to be published. We thank the NAPRALERT Data base of the University of Illinois at Chicago for allowing us access and literature retrieval. We also thank Mr. Selemani Haji for identifying the plants and Mr. Superatus Chuma and Mr. Daniel Kamala for their contribution to this work. This collaborative Lake Victoria Research (VicRes) is financially supported by Sida/SAREC through the Inter-University Council of East Africa (IUCEA). The project is VicRes Project No. 31 (see http://www.vicres.net).

\section{Author details}

${ }^{1}$ Department of Biological and Preclinical Studies, Institute of Traditional Medicine, MUHAS, P.O. Box 65001, Dar es Salaam, Tanzania. ${ }^{2}$ Department of Biological Sciences, Moi University, Eldoret, Kenya. ${ }^{3}$ Faculty of Development Studies, Mbarara University of Science and Technology (MUST), P.O. Box 1410, Mbarara, Uganda.

\section{Authors' contributions}

MJM, DFO, AW, PKM, carried out the design of the study, which is being implemented in Kenya, Tanzania and Uganda. MJM interviewed traditional healers in Bukoba Rural District, compiled the information which was subsequently synthesized by MJM, AW and DFO to this final manuscript. All authors read, revised and approved the final manuscript.

\section{Competing interests}

The authors have no competing interests in the project, and share the aspirations of the local people of Katoro ward to bring good healthcare services to their community.

Received: 29 May 2010 Accepted: 22 July 2010 Published: 22 July 2010

\section{References}

1. Mulokozi MM: The last of the bards: The story of Habibu Selemani of Tanzania (c.1929-93). Research in African Literatures 1997, 28:159-172.

2. Moshi MJ, Otieno DF, Mbabazi PK, Weisheit A: The Ethnomedicine of the Haya People of Bugabo Ward, Kagera region, north western Tanzania. Journal of Ethnobiology Ethnomedicine 2009, 5:24.

3. Moshi MJ, Innocent E, Masimba PJ, Otieno DF, Weisheit A, Mbabazi P, Lynes M, Meachem K, Hamilton A, Urassa I: Antimicrobial and brine shrimp toxicity of some plants used in traditional medicine in Bukoba District, north-western Tanzania. Tanzania Journal of Health Research 2009, 11:23-28.

4. Moshi MJ, Innocent E, Magadula JJ, Otieno DF, Weisheit A, Mbabazi PK, Nondo RSO: Brine shrimp toxicity of some plants used as traditional medicines in Kagera region, north western Tanzania. Tanzania Journal of Health Research 2010, 12:63-67.

5. Moshi MJ, Innocent E, Otieno JN, Magadula JJ, Nondo RSO, Otieno DF, Weisheit A, Mbabazi A: Antimicrobial and brine shrimp activity of Acanthus pubescens root extracts. Tanzania Journal of Health Research 2010, 12:171-175. 
6. Hamill FA, Apio S, Mubiru NK, Mosango M, Bukenya-Ziramba R, Maganyi OW, Soejarto DD: Traditional herbal drugs of southern Uganda. I. Journal of Ethnopharmacology 2000, 70:281-300.

7. Purohit K: Nilphulia (Ageratum conyzoides) poisoning in sheep. Indian Veterinary Journal 1962, 39:553.

8. Zani CL, Chaves PPG, Queiroz R, de Oliveira AB, Cardoso JE, Anjos AMG, Grandi TSM: Brine shrimp lethality assay as a prescreening system for anti-Trypanosoma cruzi activity. Phytomedicine 1995, 2:47-50.

9. Burkill IH: Dictionary of the economic products of the Malay Peninsula. Ministry of Agriculture and Cooperatives. Kuala Lumpur, Malaysia 1966, I:1.

10. Noumi E, Yomi A: Medicinal plants used for intestinal diseases in Mbalmayo region, Central Province, Cameroon. Fitoterapia 2001, 72:246-254.

11. Boily Y, van Puyvelde L: Screening of medicinal plants of Rwanda (Central Africa) for antimicrobial activity. Journal of Ethnopharmacology 1986, 16:1-13.

12. Chhabra SC, Mahunnah RLA: Plants used in traditional medicine by Hayas of the Kagera region, Tanzania. Economic Botany 1994, 48:121-129.

13. Rivera D, Obon C: The ethnopharmacology of Madeira and Porto Santo islands; A review. Journal of Ethnopharmacology 1995, 46:73-93.

14. Bajo C, Boffill MA, Campo JD, Mendez MA, Gonzalez Y, Mitjans M, Vinardell MP: In vitro study of the antioxidant and immunomodulatory activity of aqueous infusion of Bidens pilosa. Journal of Ethnopharmacology 2004, 93:319-323.

15. Chandan BK, Sharma AK, Anand KK: Boerhaavia diffusa: a study of its hepatoprotective activity. Journal of Ethnopharmacology 1991, 31:299-307.

16. Dekker TG, Fourie TG, Matthee E, Snyckers FO: An oxindole from the roots of Capparis tomentosa. Phytochemistry 1987, 26:1845-1846.

17. Brandao MGL, Grandi TSM, Rocha EMM, Sawyer DR, Krettli AU: Survey of medicinal plants used as antimalarials in the Amazon. Journal of Ethnopharmacology 1992, 36:175-182.

18. Coee FG, Anderson GJ: Screening of medicinal plants used by the Garifuna of eastern Nicaragua for bioactive compounds. Journal of Ethnopharmacology 1996, 53:29-50.

19. Ali MS, Azhar I, Amtul Z, Ahmad VU, Usmanghani K: Antimicrobial screening of some Caesalpiniaceae. Fitoterapia 1999, 70:299-304.

20. Maikere-Faniyo R, van Puyvelde L, Mutwewingabo A, Habiyaremye FX: Study of Rwandese medicinal plants used in the treatment of diarrhoea I. Journal of Ethnopharmacology 1989, 26:101-109.

21. Kuria KAM, Muriuki G, Masengo W, Kibwage I, Hoogmartens J, Laekeman GM: Antimalarial activity of Ajuga remota Benth (Labiatae) and Caesalpinia volkensii Harms (Caesalpiniaceae): in vitro confirmation of ethnopharmacological use. Journal of Ethnopharmacology 2001, 74:141-148.

22. Abreu PM, Martins ES, Kayser O, Bindseil KU, Siems K, Seemann A, Frevert J: Antimicrobial, antitumor and antileischmania screening of medicinal plants from Guinea-Bissau. Phytomedicine 1999, 6:187-195.

23. Chhabra SC, Uiso FC: Antibacterial activity of some Tanzanian plants used in traditional medicine. Fitoterapia 1991, 62:499-503.

24. Collier WA, van de Piji L: The antibiotic action of plants, especially the higher plants, with results with Indonesian plants. Chronica Naturae 1949, 105:8.

25. Sawhney AN, Khan MR, Ndaalio G, Nkunya MHH, Wevers H: Studies on the rationale of African traditional medicine. Part III. Preliminary screening of medicinal plants for antifungal activity. Pakistan Journal of Science and Industrial Research 1978, 21:193-196.

26. Hedberg I, Hedbrerg O, Madati PJ, Mshigeni KE, Mshiu EN, Samuelsson G: Inventory of plants used in traditional medicine in Tanzania. II. Plants of the families Dilleniaceae-Opiliaceae. Journal Ethnopharmacology 1983, 9:105-127.

27. Muanza DN, Kim BW, Euler KL, Williams L: Antibacterial and antifungal activities of nine medicinal plants from zaire. International Journal of Pharmacognosy 1994, 32:337-345.

28. Tona L, Kambu K, Mesia K, Cimanga K, Aspers S, de Bruyne T, Pieters L, Totte J: Biological screening of traditional preparations from some medicinal plants used as antidiarrhoeal in Kinshasa, Congo. Phytomedicine 1999, 6:59-66.

29. Gladding S: Lantana camara. Australian Journal of Medical Herbalism 1995, 7:5-9.
30. Forestieri AM, Monforte MT, Tagusa S, Trovato A, Lauk L: Antiinflammatory, analgesic and antipyretic activity in rodents of plant extracts used in African medicine. Phytotherapy Research 1996, 10:100-106.

31. Srinivasan D, Nathan S, Suresh T, Perumalsamy PL: Antimicrobial activity of certain Indian medicinal plants used in folkloric medicine. Journal of Ethnopharmacology 2001, 74:217-220.

32. Akah PA, Ekekwe RK: Ethnopharmacology of some Asteraceae family used in Nigerian traditional medicine. Fitoterapia 1995, 66:351-355.

33. Watt JM, Breyer-Brandwijk MG: Microglossa pyrifolia. The medicinal and poisonous plants of southern and eastern Africa E. + S. Livingstone, Ltd., London. Book, 2 1962, 250-251.

34. Johns T, Kokwaro JO, Kimanani EK: Herbal remedies of the Luo of Siaya district, Kenya: establishing quantitative criteria for consensus. Economic Botany 1990, 44:369-381.

35. Watt JM, Breyer-Brandwijk MG: Rubia cordifolia. The medicinal and poisonous plants of southern and eastern Africa E. + S. Livingstone, Ltd., London. Book, 2 1962, 905.

36. Wang XH: A report on 60 cases of functional uterine hemorrhage treated with "xian he gu gong tang" (decoction of agrimony and others). Zhe Jiang Zhong Yi Za Zhi 1982, 17:272-276.

37. Gupta PP, Srimal RC, Verma N, Tandon JS: Biological activity of Rubia cordifolia and isolation of an active principle. Pharmaceutical Biology 1999, 37:46-49.

38. Tona L, Ngimbi NP, Tsakala M, Mesia K, Cimanga K, Aspers S, de Bruyne T, Pieters L, Totte J, Vlietinck AJ: Antimalarial activity of 20 crude extracts from nine African medicinal plants used in Kinshasa, Congo. Journal Ethnopharmacology 1999, 68:193-203.

39. Masaba SC: The antimalarial activity of Vernonia amygdalina Del (Compositae). Transactions of the Royal Society of Tropical Medicine and Hygiene 2000, 94:694-695

40. Ssegawa P, Kasenene JM: Medicinal plantplant diversity and uses in the Sango Bay area, southern Uganda. Journal of Ethnopharmacology 2007. 113:521-540.

doi:10.1186/1746-4269-6-19

Cite this article as: Moshi et al:: Ethnomedicine of the Kagera Region, north western Tanzania. Part 2: The medicinal plants used in Katoro Ward, Bukoba District. Journal of Ethnobiology and Ethnomedicine 2010 6:19.

\section{Submit your next manuscript to BioMed Central and take full advantage of:}

- Convenient online submission

- Thorough peer review

- No space constraints or color figure charges

- Immediate publication on acceptance

- Inclusion in PubMed, CAS, Scopus and Google Scholar

- Research which is freely available for redistribution

Submit your manuscript at www.biomedcentral.com/submit
Biomed Central 